\title{
1,4,6-Tris(di-isopropylamino)-1,4,6-triboraspiro[4.4]nona-2,8-diene from the Reaction of Benzene with Subvalent Boron Species
}

\author{
Anton Meller,* Dietmar Bromm, Walter Maringgele, Andreas Heine, Dietmar Stalke, and George M. Sheldrick \\ Institut für Anorganische Chemie, Universität Göttingen, Tammannstrasse 4, D-3400 Göttingen, Federal Republic of \\ Germany
}

Reaction of benzene with sodium/potassium alloy and dichloro(di-isopropylamino)borane $(1: 2)$ in 1,2-dimethoxyethane gives, in addition to other products, the title compound, characterised by its mass (EI, FI) and NMR ( ${ }^{1} \mathrm{H},{ }^{11} \mathrm{~B}$, ${ }^{13} \mathrm{C}$ ) spectra and $X$-ray crystallography.

Recently we reported the formation of 1,4-bis(di-isopropylamino)-1,3a,4,6a-tetrahydroborolo $[3,2-b]$ borole (A) and 2,8,9-tris(di-isopropylamino)-2,8,9-triborabicyclo[3.3.1]nona-3,6-diene (B) from the reaction of benzene with subvalent species obtained by dehalogenation of $\mathrm{Cl}_{2} \mathrm{BNPr}_{2}$ with $\mathrm{Na} / \mathrm{K}$ alloy. ${ }^{1}$ Likewise novel polycyclic species $(\mathrm{C})$ and (D) were obtained starting from toluene or $m$-xylene with $\mathrm{Na} / \mathrm{K}$ and $\mathrm{F}_{2} \mathrm{BNPr}_{2}{ }_{2}{ }^{2}$ All products characterised so far contain neither spiro centres nor $\mathrm{CH}_{2}$ groups. When the reaction between $\mathrm{C}_{6} \mathrm{H}_{6}, \mathrm{Na} / \mathrm{K}$, and $\mathrm{Cl}_{2} \mathrm{BNPr}^{i}$ was conducted using only one third of a molar equivalent of benzene, a new species was isolated and characterised as 1,4,6-tris(di-isopropylamino)-1,4,6-triboraspiro[4.4]nona-2,8-diene (1). 拉 The spiro

+ For the preparation of $(1), \mathrm{Na} / \mathrm{K}$ alloy $(1 \mathrm{~mol}: 7.7 \mathrm{~g}$ of $\mathrm{Na}+26.0 \mathrm{~g}$ of $\mathrm{K})$ was dispersed in a solution of $\mathrm{C}_{6} \mathrm{H}_{6}(0.17 \mathrm{~mol})$ dimethoxyethane (DME; $500 \mathrm{ml}$ ) and the mixture stirred at $20{ }^{\circ} \mathrm{C}$ for $30 \mathrm{~h} . \mathrm{Cl}_{2} \mathrm{BNPr}_{2}$ $(0.5 \mathrm{~mol})$ was added dropwise with vigorous stirring, and the mixture stirred for $24 \mathrm{~h}$ at reflux temperature. Insoluble material (alloy and salts) was filtered off under $\mathrm{N}_{2}$. Solvent was distilled off and the residue distilled at $0.2 \mathrm{mbar}\left(125-215^{\circ} \mathrm{C}\right)$. After redistillation at 0.005 mbar $\left(105-155^{\circ} \mathrm{C}\right)$, short-path distillation $(\times 2)$ gave $9.8 \mathrm{~g}$ of a yellow viscous oil (b.p. $132{ }^{\circ} \mathrm{C}$ at $0.002 \mathrm{mbar}$, air bath temp.) which consisted mainly of (1) (field ionization MS and ${ }^{1} \mathrm{H}$ NMR intensity relationships). From this fraction colourless crystals of (1), m.p. $181^{\circ} \mathrm{C}$, separated after standing for several weeks. As losses are very high upon fractionating highly viscous melts and considerable amounts of (1) are also contained in a higher boiling fraction we assume that the amount of (1) formed in the reaction exceeds $11 \mathrm{~g}$ (about $20 \%$ ).

Spectroscopic data for (1), $\mathrm{C}_{24} \mathrm{H}_{48} \mathrm{~B}_{3} \mathrm{~N}_{3}$ : MS: EI $(70 \mathrm{eV}), m / z 411$ $(4 \%)(M)^{-*}$; FI. $m / z 411(100 \%) ; M^{+}$calc.: 411.41274 ; found: 411.41274; NMR $\left(250 \mathrm{MHz}, \mathrm{CDCI}_{3}\right.$, vs. internal $\mathrm{SiMe}_{4}$ or external $\left.\mathrm{BF}_{3} \cdot \mathrm{OEt}_{2}\right): \delta\left({ }^{11} \mathrm{~B}\right) 44.9\left(w_{1 / 2} 420 \mathrm{~Hz}\right)$ and $51.5\left(w_{1 / 2} 480 \mathrm{~Hz}\right) \mathrm{ppm}$; $\delta\left({ }^{1} \mathrm{H}\right) 0.93,0.94$, and 1.03 (all d, ${ }^{3} J_{\mathrm{HH}} 6.70 \mathrm{~Hz}$ ) $11.21,1.28$, and 1.32 (all d, ${ }^{3} J_{\mathrm{HH}} 6.90 \mathrm{~Hz}$ ) (total $\left.36 \mathrm{H}\right) ; 3.19(2 \mathrm{H})$ and $3.23(1 \mathrm{H})$ (both sept., $\left.3_{\mathrm{HH}} 6.90 \mathrm{~Hz}\right): 3.29(2 \mathrm{H})$ and $3.57(1 \mathrm{H})$ (both sept., ${ }^{3} J_{\mathrm{HH}} 6.70 \mathrm{~Hz}$ ); $1.83\left(\mathrm{dd},{ }^{3} J_{\mathrm{HH}} 1.5,{ }^{4} \mathrm{~J}_{\mathrm{HH}} 1.5 \mathrm{~Hz}, 2 \mathrm{H}, 7-\mathrm{H}_{2}\right) ; 5.65-5.69(\mathrm{~m}, 2 \mathrm{H}, 8-$, $9-\mathrm{H})$; and $7.49(\mathrm{~s}, 2 \mathrm{H}, 2-, 3-\mathrm{H}) ; \delta\left({ }^{13} \mathrm{C}\right): 21.5,21.8,22.4,23.8,25.5$, and 26.4 (all Me): $44.5(1 \mathrm{C}), 44.9(2 \mathrm{C}), 50.7(2 \mathrm{C})$, and $25.3(1 \mathrm{C})$ (all $\mathrm{CHMe}$ ); 26.8 (br., 7-C); 125.8 and 141.8 (8-, 9-C); and 161.6 (br., 2-, $3-\mathrm{C}$ ). No ${ }^{13} \mathrm{C}$ signal could be recorded for $\mathrm{C}-5$ (connected to three boron atoms)

$¥$ Crystal data for $\mathrm{C}_{24} \mathrm{H}_{48} \mathrm{~B}_{3} \mathrm{~N}_{3}$ : monoclinic, space group $P 2{ }_{1} / c, a=$ 1716.8(3), $b=1084.4(2), c=1584.1(3) \mathrm{pm}, \beta=114.31(1)^{\circ}, U=2.688$ $\mathrm{nm}^{3}, Z=4, D_{\mathrm{c}}=1.016 \mathrm{~g} / \mathrm{cm}^{3}, \mu=0.05 \mathrm{~mm}^{-1}, F(000)=912$. A crystal $(0.8 \times 0.7 \times 0.6 \mathrm{~mm})$ was mounted on a Stoe-Siemens four-circle diffractometer. 5100 reflections were measured at $-85{ }^{\circ} \mathrm{C}$ using Mo- $K_{\alpha}$ radiation $(\lambda 71.073 \mathrm{pm})$, giving 3484 independent data, of which 2987 with $F>3 \sigma(F)$ were employed for all calculations. The structure was determined by direct methods (SHELXS-86). All non-hydrogen atoms were refined anisotropically; a riding model starting from calculated positions was employed for the hydrogen atoms; 271 parameters were refined with a weighting scheme $\left[w^{-1}=\right.$ $\left.\sigma^{2}(F)+g F_{0}^{2}: g=0.0004\right]$. The final values for $R$ and $R_{\mathrm{w}}$ were 0.042 and 0.045 respectively; the final difference electron density map showed a maximum of 170 and a minimum of $-150 \mathrm{enm}^{-3}$. Atomic co-ordinates, bond lengths and angles, and thermal parameters have been deposited at the Cambridge Crystallographic Data Centre. See Notice to Authors, Issue No. 1.<smiles>[NH+]B1C=CC2B(P[PH2+])C=CC12</smiles>

(A)

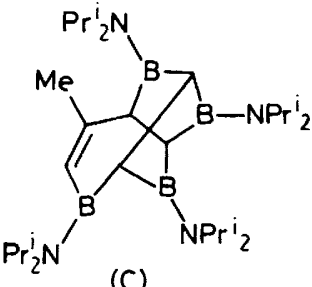

(C)

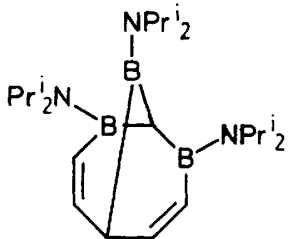

(B)

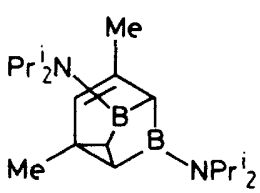

(D)

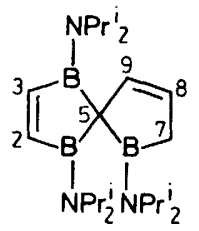

(1)

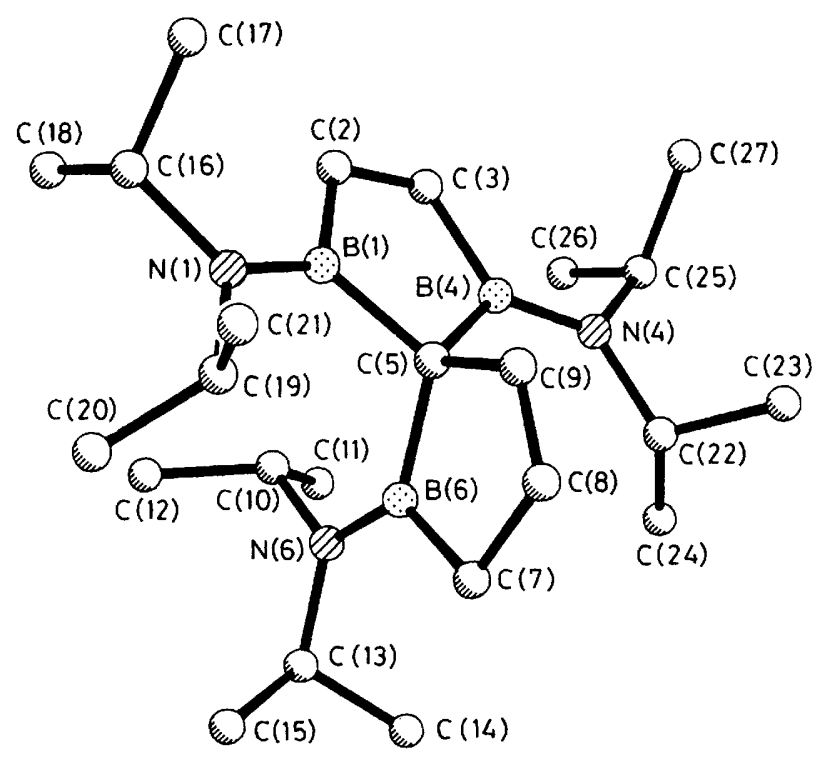

Figure 1. Molecular structure of (1); selected bond lengths (pm) and angles $\left({ }^{\circ}\right)$ : $\mathrm{C}(5)-\mathrm{B}(1) \quad 162.2(2), \mathrm{C}(5)-\mathrm{C}(9) \quad 151.9(3), \mathrm{C}(7)-\mathrm{C}(8)$ $150.0(3), \mathrm{C}(8)-\mathrm{C}(9) 132.0(2), \mathrm{C}(2)-\mathrm{C}(3) 133.6(3), \mathrm{B}(1)-\mathrm{C}(2)-\mathrm{C}(3)$ $111.7(1), \mathrm{B}(6)-\mathrm{C}(7)-\mathrm{C}(8)$ 102.6(1), $\mathrm{C}(5)-\mathrm{C}(9)-\mathrm{C}(8) 116.7(2), \mathrm{C}(7)-$ $\mathrm{C}(8)-\mathrm{C}(9) 113.0(2)$ 
compound (1) is formed by the formal insertion of 'borene' units ' $\mathrm{BNPr}_{2}{ }_{2}$ ' into the benzene ring, as for the species previously reported. ${ }^{1.2}$ Apparently this occurs via carbene type intermediates. The complexity of the process (in the liquid phase) makes a sequential mechanistic interpretation impracticable.

The single crystal $X$-ray structure of (1) (Figure 1) shows spiro, planar, five-membered rings containing one and two boron atoms, respectively. Both the bond lengths and hydrogen atoms (all could be located in difference electron density syntheses) clearly identified $C(8)-C(9)$ and $C(2)-C(3)$ as double bonds.
We thank the Volkswagenstiftung and Fonds der Chemischen Industrie for financial support.

Received, 25th October 1989; Com. 9/04593G

\section{References}

1 A. Meller, D. Bromm, W. Maringgele, D. Boehler, and G. Elter, J. Organomet. Chem., 1988, 347, 11.

2 A. Meller, U. Seebold, W. Maringgele, M. Noltemeyer, and G. M. Sheldrick, J. Am. Chem. Soc., 1989, 111, 8299. 